Moved that the Consultative Committee through its chairman communicate to the Commissioner of Education its sincere desire to aid in research in secondary education. Carried.

After a distribution of summaries of his address and of Study Helps for High-School Students, Dean J. B. Edmonson of the School of Education of the University of Michigan read his paper on The Principal's Program for Training Pupils in Habits of Study.

\title{
THE PRINCIPAL'S PROGRAM FOR TRAINING PUPILS IN HABITS OF STUDY
}

\section{J. B. EdMONSON, \\ Dean, School of Education, University of Michigan}

In the last decade, principals, supervisors, and teachers have taken an increasing interest in the pupil, in contrast to the former absorption in the subject matter of instruction. This is a change of great significance. It is certain that when all teachers devote their major attention to the pupil and make a genuine effort to adjust materials and methods of instruction to the abilities and needs of the individual pupil, our school system will have undergone a very complete revolution. With the increasing emphasis on the pupil, teachers are coming to accept the idea that their chief function is to stimulate and guide the pupil's learning rather than as formerly to impart information. Teachers are also much more concerned than formerly about effective ways of aiding the pupil in forming right habits of learning in order that he may meet with the maximum of success in his work. There has come a recognition by teachers that the secondary-school work is far from satisfactory unless pupils are trained "how to attack their work through study" and how to study "in the level of self-dependence." 1 With this development has come the demand from teachers for help and guidance from supervisors and principals in the matter of training pupils in habits of study.

For several years the instructors in one of the required courses in education in the University of Michigan have directed the students to interview freshmen. These interviews have been for the purpose of discovering the difficulties that the freshmen encounter in making

'Morrison, Practice of Teaching in the Secondary School, p. 161. 
adjustment to the university work. Year after year these university students have reported that freshmen complain particularly of the lack of specific training in matters of study. "We do not know how to study" is the common complaint of students entering our higher institutions. This is a severe indictment of the training in our secondary schools. In many cases the charge is not well founded, but too often it is true that schools have not given definite and specific training in the application of valid principles of study to different fields of learning.

It appears to be easy to secure agreement among high-school principals that the neglect to train pupils in habits of study is entirely unwarranted, but it seems to be difficult to secure agreement as to the effective plans to follow in correcting the weakness. Numerous administrative schemes for insuring the training of pupils in habits of study have been proposed and at least a dozen of these have, according to Monroe, ${ }^{1}$ been given a trial. Monroe ${ }^{2}$ declares, however, that we have not gone far in the solution of the problem. He says, "Examination of the descriptions of the plans of supervised study reveals that practically nothing is said about instructional procedures that the teacher should use in directing the learning of students. The voluminous literature on supervised study deals mainly with administrative provisions designed to facilitate the stimulation and direction of learning. The writers appear to have assumed that, if a period was provided, teachers would be able to supervise study."

In our inspection of high schools in the state of Michigan, we find that many schools are interested in the problem. of improving the study habits of pupils. In spite of this interest, it is seldom that we find a school committed to any definite policy or practice in the matter of training its pupils in effective habits of work. Through our inspection we are, therefore, urging that every high school in Michigan adopt some definite plan. We hope eventually to require that every school on the accredited list of the university shall have some clefinite plan for training pupils in study habits.

In order to help schools set up a plan, we have prepared the following plan of a program for training pupils in habits of study.

Step. I. At the beginning of the year the principal or superintendent should give a talk to the pupils on the importance of acquir-

'Monroe, Dirccting Learning in the High School, p. 408.

'I Ibid, p. 413. 
ing efficient habits of study. (For suggestions concerning points to be emphasized, see references in the bibliography.)

This step is given first place because any plan will fail unless a desire is aroused on the part of pupils to acquire effective habits of work. The reason for this advice is well stated by Kornhauser ${ }^{1}$ who declares, "There is one fundamental and indispensable requirement for effective study, more basic than any rules or technique. Without it, real study is impossible though everything else be favorable; with it, results can be achieved even in ignorance of all the fine points of how to study. This key requirement is a drizing motive, an intense desire to learn and to achieve, and interest in things intellectual, a 'will to do' in your college work. If you would learn to study, first develop a feeling that you w'ant to master your studies and that you reill master them. All else is subordinate to that." It is clearly a part of the duty of the principal to arouse pupils to an awareness of the value of right habits of study.

Step 2. On or before the time of the assembly talk to pupils, the principal or superintendent should discuss with the teachers the problem of training pupils in efficient habits of study. (Teachers should examine one or more of the books in the bibliography.)

The principal who assumes that his teachers do not need training in order to do effective work in training pupils in habits of study is making a very serious mistake. It is unfortunately true that few of our teachers have had any special training for this important kind of work. The typical teacher is well trained in testing the preparation of pupils, but poorly prepared to diagnose and care adequately for individual pupil weaknesses. If any plan for improving the technique of study is to succeed, the principal must give special attention to the training in service of his teachers. It is therefore imperative that Step 2 be a part of a principal's program.

Step 3. A list of specific study helps should be prepared by a committee of tcachers and adopted by the tcaching staff, or use may be made of the study helps issucd by the Michigan Education Association, Lansing Michigan. (These study helps sell for 75 cents per hundred. Permission is granted to any school to print its own supply.)

${ }^{1}$ Kornhauser, Hac to Study, p. 4. 
We have prepared a set of Study Helps for High School Students and have arranged for their sale at cost through the Michigan Education Association (Lansing). We have not copyrighted this material and schools have been informed that they may reprint the Study Helps.

\section{STUDY HELPS FOR HIGH-SCHOOL STUDENTS}

Arranged by Inspector J. B. Edmonson, University of Michigan, and Assistant Superintendent C. L. Goodrich, Department of Public Instruction

1. Be certain that you prepare the correct assignment in scope, content, and form. Consider such questions as: What readings, problems, experiments, or topics were assigned? Was part or all of the preparation to be written? What dangers, difficulties, or important points were emphasized by the teacher in making the assignment? Which of these study helps did the teacher urge students to follow?

2. Have a study program. Budget your time so as to have a definite time and a definite place to prepare each lesson.

(The teacher will explain how to make a study program card.)

3. Have proper study conditions and needed materials-a quiet room not too warm, plenty of light at your left, a straight chair, a table, the necessary dictionaries, rulers, pencils, and other materials.

4. Make careful preparation of advanced assignment as soon as possible after a class, but allow time in your study program for review of essential points before going to class.

5. Do your studying with vigor and determination. Work while you work. When actually tired, change your work, take exercise, or go to sleep. One must be rested in order to study effectively.

6. Learn to do two kinds of reading. Read rapidly when seeking to find major points or to make a survey of a lesson. Read cautiously and critically such material as problems, directions, explanations, and any material that must be interpreted or mastered. Never read rapidly when you should read cautiously. Acquire the habit of analyzing confusing statements. To test the efficiency of your reading and to guard against "skimming" or "day dreaming," pause at the end of 